\title{
Reasons and awareness levels of farmers on residue burning in Indo-Gangetic Plain of India : An exploratory research
}

\author{
ANURADHA ${ }^{1}$, KS KADIAN ${ }^{2}$ AND MS MEENA ${ }^{3 *}$
}

\begin{abstract}
The study examines reasons for the burning of crop residue, awareness of the impact of the burning of crop residue and government approaches to mitigating the burning. Data from 180 farmers from three districts of the state of Haryana was sought. Rank Based Quotient method was used to identify reasons. At the same time, awareness was assessed by direct questioning. The study concludes that the short window time between paddy harvesting and showing wheat was a primary reason for stubble burning. Research also shows that harvesting is expensive and time-consuming, causing farmers to burn. Most farmers were aware of the various adverse effects of burning on soil health (73.89\%), air health (100\%), and human health (81.66\%). Everybody was aware of the ban on crop residue burning and other government measures, but they have no other viable options other than burning. Policymakers, therefore, must focus on feasible options that are acceptable in farmers' socio-economic conditions.
\end{abstract}

KEYWORDS

Crop residue burning, impact, government approaches

\begin{tabular}{lcc}
\multicolumn{3}{c}{ ARTICLE INFO } \\
\hline Received on & $:$ & $23 / 11 / / 2020$ \\
Accepted on & $:$ & $27 / 02 / 2021$ \\
Published online & $:$ & $19 / 03 / 2021$ \\
\hline
\end{tabular}

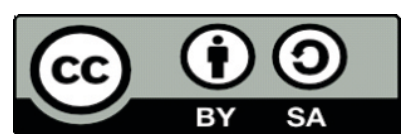

\section{INTRODUCTION}

$\mathrm{I}$ ndia is an agrarian country. Agriculture and allied sector contribute $17-18 \%$ to gross domestic product (GDP) during 2018-19. A significant part of the land is used for farming, and a wide range of crops are cultivated in its different agroecological regions (Bharati et al., 2014). Rice Wheat Cropping System (RWS) is one of the widely practiced cropping systems in India (Singh et al., 2017). About $90 \%$ of the area is concentrated in the Indo-Gangetic Plains (IGP). Therefore, due to monoculture and intensive cultivation, it is natural that a massive volume of crop residue is produced. This crop residue is estimated at around 500 million tons (M.T.), out of which 70\% accounts from cereals (rice, wheat, maize, and millets) as reported Indian Agriculture Research Institute (IARI), New Delhi (Anonymous, 2012). National Policy for Management of Crop Residue (NPMCR, 2017) analyzed that in Haryana state, the total amount of crop residue generation is $27.83 \mathrm{MT}$ among this wheat straw used for livestock feeding surplus residue (9.08MT) is being burnt every year. A viable and systematic approach lacks to deal with crop residues, or the adoption rate is low. Therefore, most farmers burn the rice residues in the fields, which leads to colossal nutrient loss besides deteriorating the environment and human health. Many forces that are compelling farmers to burn are less time available between rice harvesting and sowing of next wheat crop, combined harvesting, high cost of manual labor, lack of traditional use of crop residues, intensive cropping system, and non-availability of buyers for rice straw, etc. (Lyngdoh and Dhaliwal, 2018) which compiles farmers to go for straw burning to get rid of stubble left out after the harvest. Rice crop residues are burnt during October-November each year. The Government of India (GOI) is taking many lucrative and punitive approaches to mitigate residual crop burning for sustainable agriculture. Therefore, an investigation was carried out to identify the factors responsible for crop residue burning (CRB) and measure farmers' awareness level on the impact of CRB and Government approaches to mitigate CRB.

\section{MATERIAL AND METHODS}

\section{Study area}

Haryana is located between $27^{\circ} 37^{\prime}$ to $30^{\circ} 35^{\prime}$ latitude and between $74^{\circ} 28^{\prime}$ to $77^{\circ} 36^{\prime}$ longitude in Northern India. It is surrounded by Uttar Pradesh (UP) on the east, Punjab on the west, Uttaranchal, Himachal Pradesh \&Shivalik Hills on the north, and Delhi, Rajasthan, and Aravali Hills on the south. Haryana falls in the Agro Climatic Zone-VI, which is called the "Trans-Gangetic Plains Region." The range of rainfall in this region varied between $160-751 \mathrm{~mm}$. The cultivable area is 3.809 million hectares $(86.2 \%$ of total geographical area). The gross cropped area is 6.504 million hectares, and the area sown more than once is 2.938 million hectares with a cropping intensity of $182.39 \%$. Haryana is often called the "Food Mine" of the country. About $80 \%$ of the population of the state is agriculturedependent, directly or indirectly. Haryana is self-sufficient in producing food grains and is also a significant contributor of food grains in meeting other states' needs. The dominant cropping system is rice-wheat, cotton-wheat, and pearl milletwheat. The world-famous Basmati Rice is produced here in

\footnotetext{
${ }^{1}$ Senior Research Fellow, National Food Security Mission on Pulses at ICAR-ATARI, Zone-II, Jodhpur (Rajasthan) Choudharyanu9928@gmail.co

${ }^{2}$ Head, Division of Dairy Extension, National Dairy Research Institute, Karnal (Haryana) India

${ }^{3}$ Principal Scientist, ICAR-ATARI, Zone-II, Jodhpur Corresponding author: s.mohar.meena@gmail.com

*Corresponding author email : s.mohar.meena@gmail.com
} 
abundance, and the state has about 1 million ha under rice cultivation, which is mostly irrigated. The average state productivity is about 3.1 tonnes/ha. Haryana contributes $13.3 \%$ toward national production of nearly 4 tonnes/ha. With this tremendous amount of food grain, it also generates 27.83 MT crop residues (NPMCR, 2017). Haryana Space Applications Center (2018) observed that significant paddy stubble burning was found in Karnal, Kurukshetra, Fatehabad, Kaithal and Sirsa districts during all the previous five years. Based on this observation report, the top three districts, namely Karnal, Kurukshetra and Fatehabad, were selected purposively for this study.

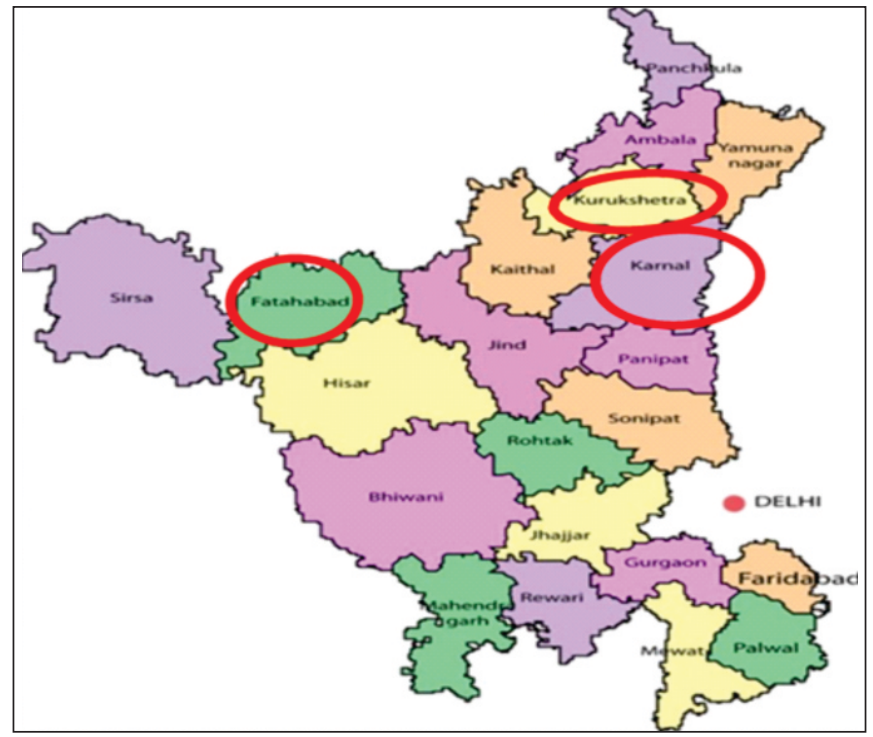

Fig. 1: Map of Haryana state with highlighted selected district

\section{Sampling plan}

Based on report of Haryana Space Applications Centre (2018), three top districts, namely Karnal, Kurukshetra and Fatehabad were selected purposively. From each selected district, two blocks were selected randomly. Nissang and Indri from Karnal, Sahabad and Thanesar from Kurukshetra and, Fatehabad and Ratiya from Fatehabaddistricts were selected. Further from each block, three villages were selected randomly. Farmers who had at least one acre of landholding and cultivating rice and wheat crops were chosen for the last five years. Hence, ten farmers from each village were randomly selected using a random stratified sampling technique.Thus, 180 farmers have constituted the sample.

\section{Measurement of variable}

The descriptive research design was applied in the present study. It was used for fact-finding with adequate interpretation. For the study, a face-to-face interview method by using an interview schedule was adopted. The schedule was first prepared in English and then translated to Hindi (native language) and then back to English to verify the consistency and content. For socio-personal variables like age, education, and annual income, direct questioning was made. Classification of operational land holding was adopted as per the classification of GOI. Structured interview schedules were used for measuring another independent variable such as extension contact, mass media exposure, innovativeness, risk orientation, ecological consciousness, possible reasons for crop residue burning, and awareness about government approaches to mitigate CRB. On a dichotomous point (yes/no), responses were captured on farmers' awareness about government approaches to mitigate CRB. The awareness level of farmers regarding the impact of CRB was also evaluated. The significant reasons for CRB were assessed based on the perception and information provided by the farmers. The reasons commonly perceived by the farmers in the study area were listed out. They were graded on the priority assigned by individual farmers, i.e., the reason which was perceived as the most important was ranked highest, and the next most crucial reason was ranked second and likewise. This information was subjected to a Rank Based Quotient (RBQ) analysis to find out why it is getting more weightage as per the farmers' rank. RBQ) was calculated using the following formula (Sabarathnam and Vennila, 1996).

\section{$\mathrm{RBQ}=\sum_{i=1}^{n} F i\left(\mathrm{n}+1-\frac{\mathrm{i}}{\mathrm{N} \cdot \mathrm{n}}\right) * 100$}

$\mathrm{F}_{\mathrm{i}}=$ Frequency of farmers for thei-thrank of constraint;

$\mathrm{N}=$ Total number of respondents;

$\mathrm{n}=$ Total number of ranks;

$\mathrm{i}=$ Rank

Table 1: Socio-personal attributes of a farmer in Haryana state, India $(n=180)$

\begin{tabular}{|c|c|c|c|}
\hline \multirow{2}{*}{$\begin{array}{l}\text { Socio-personal } \\
\text { attributes }\end{array}$} & \multirow{2}{*}{ Category } & \multicolumn{2}{|c|}{ Response } \\
\hline & & $f$ & $\%$ \\
\hline \multirow{3}{*}{ Age (years) } & Young (up to 35 years) & 33 & 18.33 \\
\hline & Middle (36 to 50 years) & 101 & 56.12 \\
\hline & Old (more than 50 years) & 46 & 25.55 \\
\hline \multirow{5}{*}{ Education } & Illiterate & 13 & 7.22 \\
\hline & Primary & 32 & 17.78 \\
\hline & Secondary & 56 & 31.11 \\
\hline & Senior secondary & 55 & 30.55 \\
\hline & Graduate and above & 24 & 13.34 \\
\hline \multirow{5}{*}{$\begin{array}{l}\text { Operational } \\
\text { landholding (ha.) }\end{array}$} & Marginal $(<1)$ & 29 & 16.11 \\
\hline & Small (1-2) & 35 & 19.44 \\
\hline & Semi-medium (2-4) & 51 & 28.34 \\
\hline & Medium (4-10) & 55 & 30.55 \\
\hline & Large $(>10)$ & 10 & 5.56 \\
\hline \multirow{3}{*}{$\begin{array}{l}\text { Annual income } \\
\text { (in lakh) }\end{array}$} & Low $(<3.6)$ & 99 & 50.00 \\
\hline & Medium (3.6-7.78) & 61 & 33.89 \\
\hline & High (>7.78) & 20 & 11.11 \\
\hline \multirow{3}{*}{ Extension contacts } & Low $(<6.80)$ & 51 & 28.33 \\
\hline & Medium (6.80-13.78) & 62 & 34.44 \\
\hline & High (> 13.78) & 67 & 37.23 \\
\hline \multirow{3}{*}{$\begin{array}{l}\text { Mass media } \\
\text { exposure }\end{array}$} & Low $(<11.95)$ & 32 & 17.78 \\
\hline & Medium (11.95-13.94) & 51 & 28.33 \\
\hline & High $(>13.94)$ & 97 & 53.89 \\
\hline \multirow{3}{*}{ Innovativeness } & Low $(<7.1)$ & 13 & 7.22 \\
\hline & Medium (7.1-9.7) & 91 & 50.56 \\
\hline & High $(>9.7)$ & 76 & 42.22 \\
\hline \multirow{3}{*}{ Risk orientation } & Low $(<10.99)$ & 51 & 28.33 \\
\hline & Medium (10.99-12.69) & 102 & 56.67 \\
\hline & High $(>12.69)$ & 27 & 15.00 \\
\hline \multirow{3}{*}{$\begin{array}{l}\text { Ecological } \\
\text { consciousness }\end{array}$} & Low $(<13.5)$ & 40 & 22.22 \\
\hline & Medium (13.5-16.4) & 75 & 41.67 \\
\hline & High (>16.4) & 65 & 36.11 \\
\hline
\end{tabular}


It can be accomplished from the study that respondents were moderately innovative, aware of the environment, but they had economic constraints to adopt management practices. Since $50 \%$ of the respondents belonged to the low-income group.

\section{Perceived reasons for CRB}

Primary perceived reasons for the burning of crop residue were assessed. The perception is based on the ranking given to a particular reason by each farmer. The ranking of the reasons was analyzed based on the RBQ method (Table 2). The study reveals that all the farmers agreed that a shorter window period is the primary reason for stubble burning in the area. Hence, this was ranked first significant reason. Manual harvesting is costly and time-consuming was ranked second reason. Haider (2013) finds that crop length, low elevation of farmland, and the distance from homestead to the farm are significant CRB determinants. Crop residual burning is easy and economical; hence it was considered as a third primary reason. Pathak et al. (2011) was also reported this reason. The shortage of human labor was the 5th primary reason for stubble burning. Less industrial demand of crop residuals was found fifth reason hence farmers are forced to burn the stubbles. Other reasons mentioned by farmers were, wheat straw is available as dry fodder, so rice straw left with no use for fodder, some farmers even resort to a cycle of three crops in a year, Mechanical harvesting leaves long stubbles in field burring is the only solution, so they ranked 6th, 7th \& 8th, respectively.

Similar results have been recorded by Yang et al. (2008) that farmers were reluctant to spend time and money on crop residue management. Few farmers responded that burning is more economical, suppressing the amount of penalty imposed by the Government; it ranked ninth. Knowledge level regarding scientific management practices is not a significant reason; the majority of respondents ranked 10 th.

Table 2: Reasons for stubble burning in Haryana state, India ( $\mathrm{n}=180)$

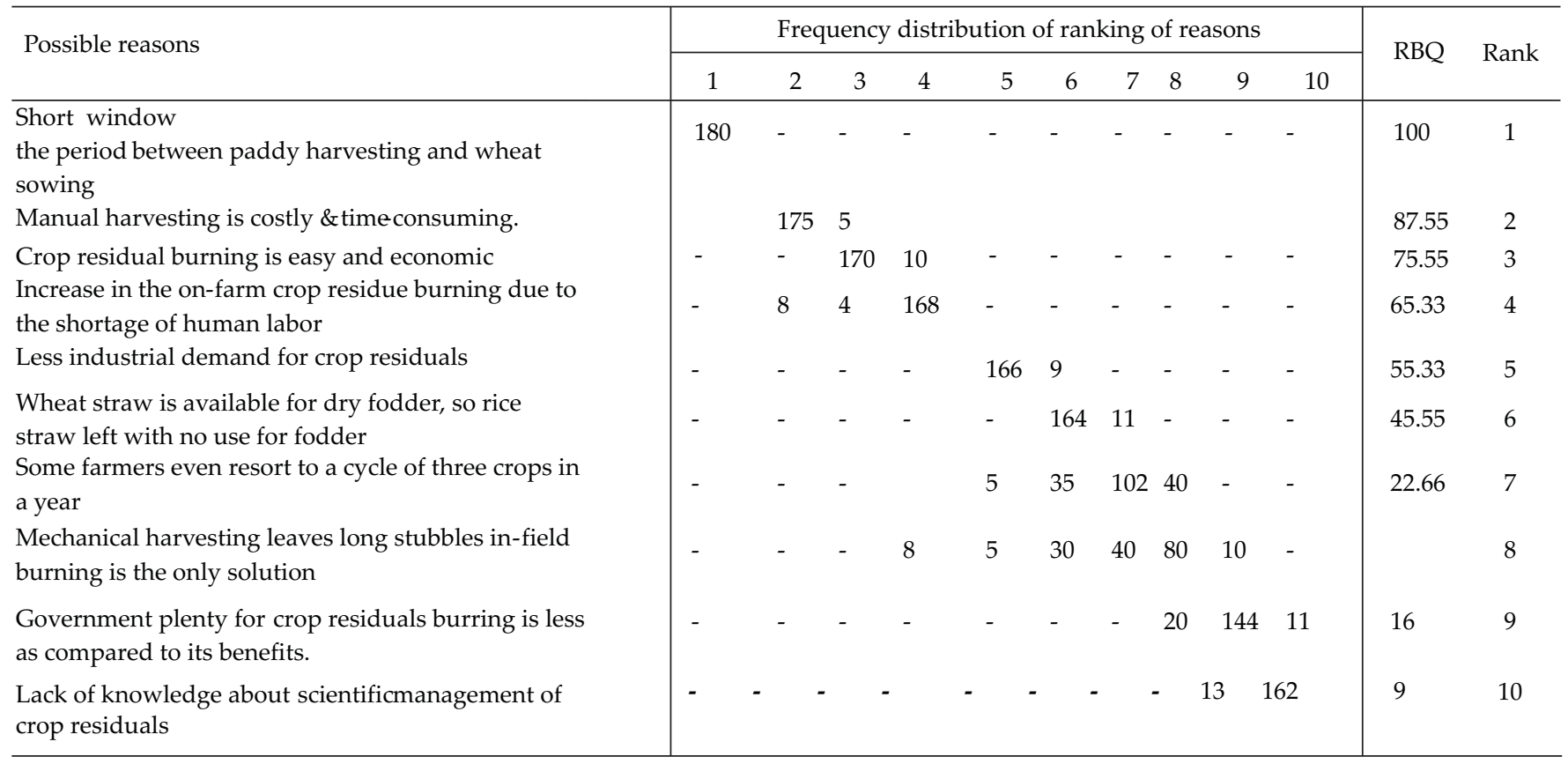

\section{Awareness regarding the impact of CRB}

Table 3 depicts that most farmers agreed that CRB harms plant health, air, human health, animal health, biodiversity, vehicular traffic and soil health. They mentioned that CRB

Table 3: Awareness of farmers on the impact of crop residue burning $(\mathrm{n}=180)$

\begin{tabular}{lcccc}
\hline Perception & Positive effect & $\begin{array}{c}\text { No } \\
\text { effect }\end{array}$ & $\begin{array}{c}\text { Negative } \\
\text { effect }\end{array}$ & $\begin{array}{r}\text { Mean } \\
\text { value }\end{array}$ \\
\hline Soil health & $f(\%)$ & $f(\%)$ & $f(\%)$ & \\
Air health & $47(26.11)$ & - & $133(73.89)$ & 1.2 \\
Human health & - & - & $180(100)$ & 1.0 \\
\hline
\end{tabular}

had no positive impact. Farmers were also revealed that we did not perceive any long-term negative impact on air quality; air quality deteriorates only during the months of burning (mainly October-November). Roy and Kaur (2015) reported that CRB negatively impacts the environment in the long run.Few farmers responded that $\mathrm{CRB}$ is not leaving any impact on health and the environment, which may be due to unawareness.

\section{Impact on soil health}

All farmers were much aware and responded that the burning of straw decreases the soil's productivity in the long-term. Farmers were aware of soil nutrients and organic carbon losses from CRB. The primary reason farmers have to add to 
the dosage for nitrogen, phosphorus, and potassium fertilizers for the next crop depleted through the burning of straw in the previous season. The results are similar to Heard et al.(2006). Respondents (26.71\%) supposed that the burning of residue increases soil temperature, so reducing the bacterial and fungal population in soil and weed can also be controlled. These results were also supported by the finding of Kanok kanjana and Garivait (2013).

\section{Impact on air health}

All respondents were well aware of air pollution caused by burning residue. Since respondents were not highly educated, they were not directly aware of carbon dioxide, greenhouse gases, Etc., but they said we perceive that air quality is impaired for a short period. It is estimated that India annually emits $144719 \mathrm{Mg}$ of total particulate matter from open-field burning of rice straw (Gadde et al., 2009, Zhang et al., 2011). The heavy smog and haze in the National Capital Delhi during winter were also blamed for the burning of crop residues and vehicular emissions. U.S. National Aeronautics and Space Administration (NASA) satellite images showed enormous quantities of crop residues burning in Punjab, Haryana, and U.P. responsible for smog and hazy northern India weather, especially over Delhi and the National Capital Region. The north and northwest winds blow into Delhi from these states. The NCR carries immense volumes of soot from crop-burning pollution.

\section{Impact on human health}

According to the report, $81.66 \%$ of farmers realized that residual burning might trigger problems linked to respiration, eye pain, low vision, etc. According to a study, burning crop residues contributes to smoke release, greenhouse gases such as carbon dioxide, methane, nitrous oxide that cause global warming, and vast quantities of pollutants that cause detrimental effects on human healing (Anonymous, 2012). The resulting smoke from the burning of crop residue can become a health threat as it can cause numerous and permanent effects, particularly on the lung function of children (Awasthi et al., 2010), leading to respiratory and eye problems.

\section{Awareness about Government approaches to mitigate CRB}

Table 4 reflects that farmers were well aware of approaches taken by the Government to mitigate CRB. All of the respondents were aware that the Government is promoting crop diversification and aware of the ban on crop residue burning. Most (95.5\%) farmers were aware that a penalty is being imposed on any offending farmer and the National Green Tribunal (NGT) has imposed fines ranging between Rs 2,500 and Rs 15,000 on farmers to prevent them from burning paddy fields. Nevertheless, despite awareness about the ban, they still practiced burning because they said they do not have a feasible alternative. Roy and Kaur (2015) find similar results. Farmers $(94.44 \%)$ responded that the government agencies detect crop residue burning. They are also working for prevention. However, $90 \%$ of farmers were well aware that the Government is providing subsidies on agri-implements. Most respondents $(79.44 \%)$ responded that outreach and public awareness campaigns regarding the effect of open burning and ways to combat this method. Only a few farmers were aware of the establishment of biomass-based power projects for utilizing more significant amounts of paddy straw $(20.54 \%)$, the establishment of a market place for crop residue (11.11\%), and Section 144 of the Civil Procedure Code (CPC) to ban burning of paddy straw $(10 \%)$.

The most significant shortfall was observed from the present study, although respondents were aware of the Government's strict actions. However, still the adoption rates of management practices were lower. This gap was may be due to improper knowledge about alternative options for management and less credit facility available to them. Hence, there is a need to connect farmers with the market place/input industry such as paper industry, brick kilns, biomass-based power plants, etc., the awareness campaign should be organized and machinery availability should be increased by increasing the number of custom hiring centers.

Table 4: Awareness on government approaches to mitigate crop residue burning in Haryana, India $(n=180)$

\begin{tabular}{lcc}
\hline Approaches & $\begin{array}{c}\text { Yes } \\
(\%)\end{array}$ & $\begin{array}{c}\text { No } \\
(\%)\end{array}$ \\
\hline $\begin{array}{l}\text { Ban on crop residue burning } \\
\text { The penalty is being imposed on any } \\
\text { offending farmer }\end{array}$ & $\begin{array}{c}100 \\
\text { Detection and prevention of crop burning }\end{array}$ & 0.00 \\
Establishment of a marketplace for crop residue & 94.44 & 5.56 \\
Outreach and public awareness campaigns & 79.11 & 88.89 \\
$\begin{array}{l}\text { Subsidy on agri-implements } \\
\text { Crop diversification }\end{array}$ & 90.00 & 10.00 \\
$\begin{array}{l}\text { Establishment of a larger number of } \\
\text { biomass-based power projects }\end{array}$ & 100 & 0.00 \\
utilizing more significant amounts of & 20.54 & 79.46 \\
paddy straw & & \\
Section 144 of the Civil Procedure Code & & \\
(CPC) ban the burning of paddy & 18 & 10.00 \\
\hline
\end{tabular}

\section{CONCLUSION}

The study depicts that short window time between paddy harvesting and showing wheat was a primary reason for stubble burning. Research also shows that harvesting is expensive and time-consuming, causing farmers to burn. Most farmers were aware of the various adverse effects of burning on soil health, air health, and human health. Everybody was aware of the ban on crop residue burning and other government measures, but they have no other viable options other than burning. Policymakers, therefore, must focus on feasible options that are acceptable in farmers' socioeconomic conditions. Community-based organizations, nongovernmental organizations (NGOs), and Krishi Vigyan Kendras must play a more active role in raising awareness for control of the burning of stubbles. After careful consultation with the farmers, the state government should devise more successful policies and increase farmers' capacity to manage residue more competently rather than burning alone. 


\section{REFERENCES}

Anonymous. 2012. Crop Residues Management with Conservation Agriculture: Potential, Constraints and Policy needs. Pp 56-69. Indian Agricultural Research Institute, New Delhi.

Awasthi A, Singh N, Mittal S and Agarwal R. 2010. Effects of agriculture crop residue burning on children and young on PFTs in northwest India. Science of the Total Environment 408 (20): 4440-4445.

Bharati RC, Singh KM, Chandra N and Singh AK. 2014. Economic condition of eastern region of India -An statistical evaluation. Journal of AgriSearch 1 (3):173-179.

Gadde B, Bonnet S, Menke C and Garivait S. 2009. Air pollutant emissions from rice straw open field burning in India, Thailand, and the Philippines. Environmental Pollution 157: 1554-1558.

Haider MZ. 2013. Determinants of rice residue burning in the field. Journal of Environmental Management 128: 15-21.

Heard J, Cavers C, and Adrian G. 2006. Up in smoke-nutrient loss with straw burning. Better Crops 90(3): 10-11.

Kanokkanjana K, and Garivait S. 2013. Alternative rice straw management practices to reduce field open burning in Thailand. International Journal of Environmental Science and Development 4(2): 119.

Lyngdoh L and Dhaliwal RK. 2018. Perception of extension personnel and farmers towards effect on open burning in rice and wheat cropping system. Indian Journal of Ecology 45(4): 881-887.

Monitoring crop stubble burning in Haryana using satellite data,
HSAC, report (2018) accessed from: http://hrsdi.in/ activefire/ LIST/Note\%20Stubble\%20burning\%202018.pdf (accessed on 12 , November, 2019)

NPMCR. 2017. Available online: http://agricoop.nic.in/sites/ default/files/NPMCR1.pdf(accessed on 12, Dec. 2020).

Pathak H, Saharawat YS, Gathala M and Ladha JK. 2011. Impact of resource-conserving technologies on productivity and greenhouse gas emissions in the rice-wheat system. Greenhouse Gases. Science and Technology 1(3): 261-277.

Roy P and Kaur M. 2015. Status and Problems of Paddy Straw Management in West Bengal. International Journal of Advances in Agricultural \& Environmental Engineering 2(1): 144-152.

Sabarathnam VE and Vennila 1996. Estimation of Technological Needs and Identification of Farmers' Problems for Formulation of Research and Extension Programmes in Agricultural Entomology. Experimental Agriculture 32: 87-90.

Singh AK, Singh AK, Kumar R, Prakash V Sundaram PK and Yadav SK. 2017. Indian Cereals Saga: Standpoint and Way Forward. Journal of AgriSearch 4 (1): 1-10.

Yang S, He H, Lu S, Chen D and Zhu J. 2008. Quantification of crop residue burning in the field and its influence on ambient air quality in Suqian, China. Atmospheric Environment 42: 1961-1969.

Zhang H, Hu D, Chen J, Ye X, Wang SX, Hao JM and An Z. 2011. Particle size distribution and polycyclic aromatic hydrocarbons emissions from agricultural crop residue burning. Environmental Science \& Technology 45 (13): 5477-5482.

Citation:

Anuradha, Kadian KS and Meena MS.2021. Reasons and Awareness Levels of Farmers on Residue Burning in Indo-Gangetic Plain of India: An Exploratory Research. Journal of AgriSearch 8(1):62-66 